\title{
Bacillus aurantiacus sp. nov., an alkaliphilic and moderately halophilic bacterium isolated from Hungarian soda lakes
}

Correspondence Andrea K. Borsodi bandrea@ludens.elte.hu

\author{
Andrea K. Borsodi, ${ }^{1}$ Károly Márialigeti, ${ }^{1}$ Gitta Szabó, ${ }^{1}$ Márton Palatinszky, ${ }^{1}$ \\ Beatrix Pollák, ${ }^{1}$ Zsuzsa Kéki, ${ }^{1}$ Attila L. Kovács, ${ }^{2}$ Peter Schumann ${ }^{3}$ \\ and Erika M. Tóth ${ }^{1}$
}
${ }^{1}$ Department of Microbiology, Eötvös Loránd University, Pázmány P. sétány 1/C, H-1117 Budapest, Hungary
${ }^{2}$ Department of Anatomy, Cell and Developmental Biology, Eötvös Loránd University, Pázmány P. sétány 1/C, H-1117 Budapest, Hungary
${ }^{3} \mathrm{DSMZ}$ - Deutsche Sammlung von Mikroorganismen und Zellkulturen GmbH, Inhoffenstr. 7b, D-38124 Braunschweig, Germany

\begin{abstract}
Three alkaliphilic and moderately halophilic strains designated $\mathrm{K} 1-5^{\top}, \mathrm{K} 1-10$ and $\mathrm{B} 1-1$, characterized by optimal growth at $\mathrm{pH} 9.0-10.0$ and at 3-7\% (w/v) $\mathrm{NaCl}$, were isolated from extremely shallow, alkaline soda lakes located in Hungary. Cells of the strains are Gram-positive, straight rods and form a central to subterminal, ellipsoidal endospore. The isolates are strictly aerobic, catalase-positive, oxidase-negative and contain a peptidoglycan of type $A 1 \gamma$ based on meso-diaminopimelic acid. In strain $\mathrm{K} 1-5^{\top}$, menaquinone-7 (MK-7) is the predominant isoprenoid quinone and anteiso- $\mathrm{C}_{15: 0}$ is the major cellular fatty acid. The DNA G+C content of strain $\mathrm{K} 1-5^{\top}$ is 42.9 mol\%. 16S rRNA gene-based phylogenetic analysis revealed that the strains exhibit levels of sequence similarity of less than $95.8 \%$ to known Bacillus species. According to the polyphasic characterization, the strains represent a novel species, for which the name Bacillus aurantiacus sp. nov. is proposed. The type strain is $\mathrm{K} 1-5^{\top}\left(=\mathrm{DSM} 18675^{\top}=\mathrm{CCM} 7447^{\top}\right.$ $=$ NCAIM B002265 ${ }^{\top}$ ).
\end{abstract}

Natural alkaline environments, especially the widely distributed soda lakes, contain dense populations of extremophile micro-organisms from phylogenetically diverse lineages (Jones et al., 1998; Martins et al., 2001; Rees et al., 2004). Several alkaliphilic and/or halophilic Bacillus species originating from extreme habitats have been described (Agnew et al., 1995; Nielsen et al., 1995; Lim et al., 2006a, b) and studied extensively not only because of their taxonomic and ecological significance but also for the applicability of the isolated strains for biotechnological and industrial purposes (Horikoshi, 1996; Nogi et al., 2005). The shallow soda lakes (approx. 0.5-1.5 $\mathrm{m}$ deep) located in Hungary are the most western representatives of such lakes that lie across Eurasia and are structurally dissected by their extended reed coverage. In the last few years, the phylogenetic diversity of bacterial communities adapted to these special environments

The GenBank/EMBL/DDBJ accession numbers for the 16S rRNA gene sequences of strains $\mathrm{K} 1-5^{\top}, \mathrm{K} 1-10$ and $\mathrm{B} 1-1$ are AJ605773, AJ605772 and AJ606036, respectively.

Detailed Biolog GP2 test results for the novel strains are available as supplementary material with the online version of this paper. has been studied thoroughly by cultivation-based methods. Different alkalitolerant and alkaliphilic Bacillus species were predominant within the cultivable bacteria not only from the water and sediment of the lakes but also from the periphyton communities of submerged stems of Phragmites australis (Borsodi et al., 2005, 2007). The aim of the present work was a polyphasic characterization of strains of a novel alkaliphilic and moderately halophilic Bacillus species isolated from two extremely shallow alkaline soda lakes.

Samples for isolation of bacterial strains were collected from the upper 3-5 cm sediment layers of two extremely shallow soda lakes in May 2003. Strains $\mathrm{K} 1-5^{\mathrm{T}}$ and K1-10 were isolated from Kelemen-szék $\left(46^{\circ} 47^{\prime} \mathrm{N} 19^{\circ} 11^{\prime} \mathrm{E}\right)$, while B11 was from Böddi-szék ( $\left.46^{\circ} 45^{\prime} \mathrm{N} 19^{\circ} 09^{\prime} \mathrm{E}\right)$ situated in the Kiskunság National Park, Hungary. Serially diluted sediment samples were spread on modified seawater medium 246 (http://www.dsmz.de) consisting of $10.0 \mathrm{~g}$ beef extract, $10.0 \mathrm{~g}$ peptone, $20.0 \mathrm{~g}$ agar, $250.0 \mathrm{ml}$ tap water and $750 \mathrm{ml}$ seawater. Artificial seawater (ASW) contained $23.6 \mathrm{~g} \mathrm{NaCl}$, $0.64 \mathrm{~g} \mathrm{KCl}, 4.53 \mathrm{~g} \mathrm{MgCl} .6 \mathrm{H}_{2} \mathrm{O}, 5.94 \mathrm{~g} \mathrm{MgSO}_{4} .7 \mathrm{H}_{2} \mathrm{O}$ and $1.3 \mathrm{~g} \mathrm{CaCl}_{2} \cdot 2 \mathrm{H}_{2} \mathrm{O}$ (1 ${ }^{-1}$ distilled water). The $\mathrm{pH}$ of the medium was adjusted to 9.0. Single colonies that developed 
after 6 days of incubation at $28{ }^{\circ} \mathrm{C}$ were isolated. The same medium was used for maintenance of the strains.

Colony morphology was observed on modified seawater medium 246 by using a stereomicroscope. The shape, size and arrangement of the cells were studied in Gram-stained preparations (Claus, 1992). Endospore staining was carried out according to the method of Murray et al. (1994). Motility of 12 and $24 \mathrm{~h}$ old cells was observed by phasecontrast microscopy of hanging-drop preparations. The endospore morphology and the occurrence of flagella of the strains developed in modified seawater medium 246 ( $\mathrm{pH}$ 9.0) were studied by transmission electron microscopy as described by Borsodi et al. (2003).

Physiological and biochemical tests such as catalase and Kovács' oxidase activity, Hugh and Leifson's oxidationfermentation test of D-glucose, methyl-red and Barritt's Voges-Proskauer tests, nitrate reduction to nitrite or nitrogen (method 1), Baird-Parkers' phosphatase activity, production of $\mathrm{H}_{2} \mathrm{~S}$ from cysteine and indole from tryptophan, aesculin hydrolysis, tyrosine decomposition, phenylalanine deamination and Simmons' citrate utilization were performed as described by Barrow \& Feltham (2003). Urease activity and hydrolysis of casein, gelatin, starch and Tween 80 were examined according to Smibert \& Krieg (1994). Anaerobic growth was determined by incubation of strains on modified medium 246 for 7 days at $28{ }^{\circ} \mathrm{C}$ in a Forma Scientific anaerobic chamber. The $\mathrm{pH}$ range for growth was determined in nutrient broth $(3.0 \mathrm{~g}$ beef extract and $5.0 \mathrm{~g}$ peptone $\mathrm{l}^{-1}$, supplemented with $50 \mathrm{~g}$ $\mathrm{NaCl}$ ) and $\mathrm{pH}$ was adjusted to $7.0-12.0$ with $\mathrm{KOH}$ at intervals of $0.5 \mathrm{pH}$ units. The $\mathrm{NaCl}$ requirement for growth was studied in nutrient broth adjusted to $\mathrm{pH} 9.0$ and supplemented with $0-20 \%(\mathrm{w} / \mathrm{v}) \mathrm{NaCl}$ at intervals of $1 \%$ $\mathrm{NaCl}$. The influence of temperature on growth was investigated by incubation of strains cultivated on modified seawater medium 246 between 4 and $48{ }^{\circ} \mathrm{C}$ at intervals of $1{ }^{\circ} \mathrm{C}$. All physiological tests were performed in duplicate at $28{ }^{\circ} \mathrm{C}$ except for temperature range determinations and were supplemented with ASW containing $5 \%(\mathrm{w} / \mathrm{v}) \mathrm{NaCl}$.

For Biolog GP2 sole carbon source investigations, strains were cultivated on Biolog universal growth medium supplemented with $1 \%$ glucose and $5 \% \mathrm{NaCl}(\mathrm{pH}$ was adjusted to 9.0). After $16 \mathrm{~h}$ of incubation at $28{ }^{\circ} \mathrm{C}$, the turbidity of the cell suspension $(0.9 \%, \mathrm{w} / \mathrm{v}$, saline solution, $\mathrm{pH}$ 9.0) was set according to the instructions for Grampositive spore-forming bacteria (GP-ROD $\mathrm{SB}$ ) and the absence of endospores was checked microscopically. Development of the purple colour of the indicator due to substrate oxidation was measured as $A_{590}$ after 24 and $48 \mathrm{~h}$ of incubation at $28{ }^{\circ} \mathrm{C}$. Carbon source utilization was regarded as positive when the given absorbance was higher than the mean absorbance on a microplate.

The cell-wall diamino acid of strain $\mathrm{K} 1-5^{\mathrm{T}}$ was determined from whole-cell hydrolysates as described by Hasegawa et al. (1983). Isoprenoid quinones were extracted according to the method of Collins et al. (1977) and the profile was analysed by HPLC (HP 9001) (Groth et al., 1997) following the cultivation of cells in liquid rich medium (Yamada \& Komagata, 1972) supplemented with $50 \mathrm{~g} \mathrm{NaCl}$ and adjusted to $\mathrm{pH}$ 9.0. After $24 \mathrm{~h}$ of cell cultivation on tryptic soy agar medium (Difco) supplemented with $50 \mathrm{~g} \mathrm{NaCl}$ and adjusted to $\mathrm{pH}$ 9.0, cellular fatty acids were extracted according to Stead et al. (1992) and were analysed by GC (Groth et al., 1996). Polar lipids were determined according to the method described by Minnikin et al. (1979).

DNA for determination of the base composition of genomic DNA and for DNA-DNA hybridization was isolated using a French pressure cell (Thermo Spectronic) and was purified by chromatography on hydroxyapatite as described by Cashion et al. (1977). For determination of the base composition, the DNA was degraded to nucleosides by using P1 nuclease and bovine intestinal mucosa alkaline phosphatase as described by Mesbah et al. (1989). The nucleosides were separated by reversed-phase HPLC by using the HPLC system mentioned above according to the method described by Tamaoka \& Komagata (1984). The $\mathrm{G}+\mathrm{C}$ content of the DNA was calculated from the ratio of deoxyguanosine to thymidine. DNA-DNA hybridization was carried out in $2 \times$ SSC buffer at $67{ }^{\circ} \mathrm{C}$ as described by De Ley et al. (1970), with the modifications described by Huß et al. (1983), using a model Cary 100 Bio UV/Vis spectrophotometer equipped with a Peltier-thermostatted $6 \times 6$ multicell changer and a temperature controller with in-situ temperature probe (Varian).

DNA from the strains were extracted by using the Bacterial Genomic DNA Mini-prep kit (V-GENE) according to the manufacturer's instructions and 16S rRNA genes were amplified by PCR with the universal eubacterial primer pair of $27 \mathrm{f}$ ( $5^{\prime}$-AGAGTTTGATCMTGGCTCAG-3') and 1492r (5'-TACGGYTACCTTGTTACGACTT-3'). PCR products were purified using the Viogene PCR-M Clean

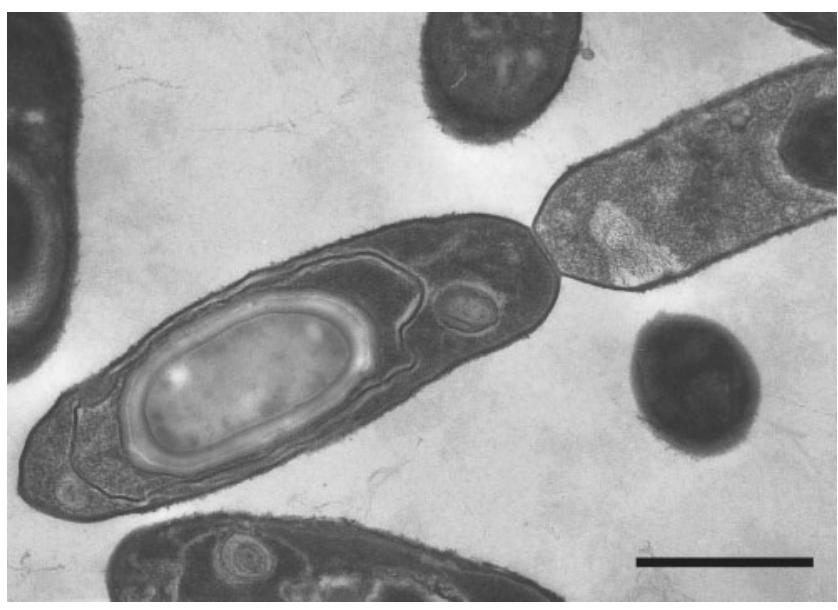

Fig. 1. Longitudinal section showing a central to subterminal ellipsoidal endospore-forming cell of Bacillus aurantiacus sp. nov. $\mathrm{K} 1-5^{\top}$. Bar, $1 \mu \mathrm{m}$. 
Table 1. Differential characteristics between strain $\mathrm{K} 1-5^{\top}$ (Bacillus aurantiacus sp. nov.) and closely related species

Reference species: 1, B. agaradhaerens (data from Nielsen et al., 1995); 2, B. cellulosilyticus (Nogi et al., 2005); 3, B. clarkii (Nielsen et al., 1995); 4, B. salarius (Lim et al., 2006a); 5, B. saliphilus (Romano et al., 2005); 6, B. taeanensis (Lim et al., 2006b); 7, B. vedderi (Agnew et al., 1995; Nogi et al., 2005). +, Positive; -, negative; ND, no data available.

\begin{tabular}{|c|c|c|c|c|c|c|c|c|}
\hline Characteristic & $\mathrm{K} 1-5^{\mathrm{T}}$ & 1 & 2 & 3 & 4 & 5 & 6 & 7 \\
\hline Colony pigmentation & Orange & White & Cream & Yellow & Cream & Yellow & Cream & Yellow-white \\
\hline Cell morphology & Rod & Rod & Rod & Rod & Rod & Cocci & Rod & Rod \\
\hline Cell size $(\mu \mathrm{m})$ & $0.8-1.0 \times 3.2-4.5$ & $0.5-0.6 \times 2.0-5.0$ & $0.3-0.4 \times 2.0-3.0$ & $0.6-0.7 \times 2.0-5.0$ & $0.3-0.5 \times 1.3-1.9$ & $0.8-0.9$ & $0.5-1.2 \times 1.2-1.9$ & $\mathrm{ND}$ \\
\hline Spore shape ${ }^{\star}$ & $\mathrm{E}$ & $\mathrm{E}$ & $\mathrm{E}$ & $\mathrm{E}$ & s & - & $\mathrm{E}$ & s \\
\hline Spore location $\dagger$ & $\mathrm{ST} / \mathrm{C}$ & ST & ST & $\mathrm{T}$ & $\mathrm{T}$ & - & $\mathrm{T}$ & $\mathrm{T}$ \\
\hline Swollen sporangia & - & + & + & + & + & - & + & $\mathrm{ND}$ \\
\hline Motility & - & + & + & $\mathrm{ND}$ & - & - & + & + \\
\hline Flagellation & - & ND & Peritrichous & $\mathrm{ND}$ & - & - & Polar & Peritrichous \\
\hline Oxidase & - & - & - & - & + & + & + & + \\
\hline Anaerobic growth & - & - & $\mathrm{ND}$ & - & - & $\mathrm{ND}$ & ND & + \\
\hline Nitrate reduction to nitrite & - & + & + & + & - & + & + & + \\
\hline \multicolumn{9}{|l|}{ Hydrolysis of: } \\
\hline Aesculin & - & + & $\mathrm{ND}$ & + & + & ND & + & + \\
\hline Casein & - & + & - & + & - & - & - & - \\
\hline Gelatin & - & + & - & + & ND & + & - & + \\
\hline Starch & - & + & + & - & - & - & + & - \\
\hline Tween 80 & + & ND & $\mathrm{ND}$ & $\mathrm{ND}$ & - & ND & - & $\mathrm{ND}$ \\
\hline Tyrosine decomposition & - & $\mathrm{ND}$ & $\mathrm{ND}$ & $\mathrm{ND}$ & - & + & + & $\mathrm{ND}$ \\
\hline Phenylalanine deamination & - & - & $\mathrm{ND}$ & - & ND & - & $\mathrm{ND}$ & $\mathrm{ND}$ \\
\hline Temperature optimum $\left({ }^{\circ} \mathrm{C}\right)$ & 28 & 30 & 37 & 30 & 30 & 37 & 35 & ND \\
\hline \multicolumn{9}{|l|}{$\mathrm{NaCl}(\% \mathrm{w} / \mathrm{v})$ for growth } \\
\hline Range & $0-15$ & $0-16$ & $0-12$ & $0-15$ & $3-20$ & $>0-25$ & $0-12$ & $0-8$ \\
\hline Optimum & $3-7$ & $\mathrm{ND}$ & $\mathrm{ND}$ & $\mathrm{ND}$ & $10-12$ & 16 & $2-5$ & ND \\
\hline \multicolumn{9}{|l|}{$\mathrm{pH}$ for growth } \\
\hline Range & $8.0-12.0$ & $>7.0$ & $8.0-10.0$ & $>7.0$ & $6.8-9.5$ & $7.0-10.0$ & $5.5-9.0$ & $9.0-10.0$ \\
\hline Optimum & $9.5-10.0$ & 10.0 & $9.0-10.0$ & 10.0 & 8.0 & 9.0 & 7.5 & 10.0 \\
\hline DNA G $+C$ content $(\mathrm{mol} \%)$ & 42.9 & $39.3-39.5$ & 39.6 & $42.4-43.0$ & 43.0 & 48.4 & 36.0 & 38.3 \\
\hline
\end{tabular}

${ }^{\star}$ E, Ellipsoidal; s, spherical.

$\dagger \mathrm{C}$, Central; sT, subterminal; T, terminal. 
Up system following the manufacturer's instructions. Sequence analysis of the strains was accomplished by using the Big Dye Terminator cycle sequencing kit v. 3.1 according to the procedure provided by the manufacturer (Applied Biosystems). An ABI 310A Genetic Analyzer (Applied Biosystems) was used for automated sequence analysis. The sequences were aligned against the RDP database release 7.1 (Maidak et al., 1996) using the ARB program package (Strunk \& Ludwig, 1995). All sequences were also compared to $16 \mathrm{~S}$ rRNA gene sequences available in GenBank by using the BLAST search program (http:// www.ncbi.nlm.nih.gov/blast/). Evolutionary distances were calculated using Kimura's two-parameter and Jukes-Cantor methods (Kimura, 1980; Jukes \& Cantor, 1969). Phylogenetic trees were constructed by three different treeing algorithms: neighbour-joining (Saitou \& Nei, 1987), maximum-likelihood (Felsenstein, 1981) and least-squares (De Soete, 1983). Tree topology was re-examined by the bootstrap method of resampling (Felsenstein, 1985) using 1000 bootstraps.
Strains $\mathrm{K} 1-5^{\mathrm{T}}, \mathrm{K} 1-10$ and $\mathrm{B} 1-1$ formed circular, entire, smooth and convex colonies, goldish orange in colour on modified seawater medium 246. Straight, rod-shaped $(0.8-$ $1.0 \times 3.2-4.5 \mu \mathrm{m})$ cells of the strains, occurring mainly singly or in pairs and occasionally in short chains, stained Gram-positive and were not motile in wet-mount preparations. Cells formed central to subterminal, ellipsoidal endospores in unswollen sporangia (Fig. 1). All three strains grew in nutrient broth medium as well as in this medium supplemented with up to $15 \% \mathrm{NaCl}$ (strain K1$5^{\mathrm{T}}$ ), $13 \% \mathrm{NaCl}$ (strain $\mathrm{K} 1-10$ ) or $12 \% \mathrm{NaCl}$ (strain B1-1). The differential characteristics of strain $\mathrm{K} 1-5^{\mathrm{T}}$ and type strains of related Bacillus species are presented in Table 1.

In Biolog GP2 microplates, all three strains oxidized Tween 40, $\alpha$-D-glucose, 3-methylglucose, acetic acid, $\gamma$-hydroxybutyric acid, pyruvic acid and glycerol. Strain-dependent utilization of Tween 80, $\mathrm{N}$-acetyl-D-glucosamine, $\mathrm{N}$-acetylD-mannosamine, amygdalin, D-gluconic acid, myo-inositol,

Table 2. Fatty acid profiles of the novel strains and related species

Reference species: 1, B. agaradhaerens (data from Lim et al., 2006b); 2, B. cellulosilyticus (Nogi et al., 2005); 3, B. clarkii (Lim et al., 2006a); 4, B. salarius (Lim et al., 2006a); 5, B. saliphilus (Romano et al., 2005); 6, B. taeanensis (Lim et al., 2006b); 7, B. vedderi (Nogi et al., 2005). Fatty acids representing less than $0.5 \%$ are not shown. D, Detected; ND, not detected.

\begin{tabular}{|c|c|c|c|c|c|c|c|c|c|c|}
\hline Fatty acid & $\mathrm{K} 1-5^{\mathrm{T}}$ & K1-10 & B1-1 & 1 & 2 & 3 & 4 & 5 & 6 & 7 \\
\hline $\mathrm{C}_{14: 0}$ & 0.69 & 0.82 & 0.76 & 0.91 & 2 & 0.78 & & & & \\
\hline $\mathrm{C}_{15: 0}$ & ND & ND & ND & & & 0.64 & & & 3.29 & \\
\hline $\mathrm{C}_{16: 0}$ & 2.43 & 2.77 & 3.22 & 5.28 & 42 & 2.25 & & & 5.41 & 3 \\
\hline $\mathrm{C}_{17: 0}$ & $\mathrm{ND}$ & $\mathrm{ND}$ & $\mathrm{ND}$ & & 1 & & & D & & \\
\hline $\mathrm{C}_{18: 0}$ & $\mathrm{ND}$ & $\mathrm{ND}$ & $\mathrm{ND}$ & 1.41 & 6 & & & & & 3 \\
\hline iso- $\mathrm{C}_{14: 0}$ & 1.53 & 1.71 & 1.61 & 0.91 & 2 & 9.67 & 8.95 & & 2.46 & 3 \\
\hline iso- $\mathrm{C}_{15: 0}$ & 13.14 & 13.18 & 11.56 & 25.42 & 13 & 18.45 & 6.60 & $\mathrm{D}$ & 40.63 & 20 \\
\hline iso- $\mathrm{C}_{16: 0}$ & 7.40 & 7.00 & 8.26 & 1.66 & 4 & 11.35 & & & 0.96 & 9 \\
\hline iso- $\mathrm{C}_{17: 0}$ & 1.40 & 1.54 & 1.65 & 4.18 & 2 & 3.35 & 53.13 & & 1.81 & 14 \\
\hline iso- $\mathrm{C}_{18: 0}$ & $\mathrm{ND}$ & $\mathrm{ND}$ & $\mathrm{ND}$ & & & & & & & 1 \\
\hline iso- $\mathrm{C}_{19: 0}$ & ND & ND & ND & & & & & & & 1 \\
\hline anteiso- $\mathrm{C}_{15: 0}$ & 55.49 & 53.41 & 52.63 & 40.18 & 23 & 35.64 & 18.67 & 89.0 & 25.89 & 15 \\
\hline anteiso- $\mathrm{C}_{17: 0}$ & 12.06 & 11.07 & 14.34 & 7.39 & 5 & 8.40 & & & & 6 \\
\hline $\mathrm{C}_{16: 1} \omega 7 c$ & 2.32 & 3.02 & 2.62 & & & & & & & \\
\hline $\mathrm{C}_{16: 1} \omega 11 c$ & ND & ND & $\mathrm{ND}$ & 1.93 & & & & & 2.12 & \\
\hline $\mathrm{C}_{18: 1} \omega 9 c$ & ND & ND & ND & 3.47 & & & & & & \\
\hline iso- $\mathrm{C}_{16: 1}$ & 1.11 & 1.42 & 1.03 & & & & & & & 1 \\
\hline iso- $\mathrm{C}_{17: 1}$ & ND & ND & $\mathrm{ND}$ & & & & & & & 7 \\
\hline iso- $\mathrm{C}_{17: 1} \omega 5 c$ & 0.70 & 0.83 & 0.59 & & & 1.09 & & & & \\
\hline iso- $\mathrm{C}_{17: 1} \omega 10 c$ & ND & $\mathrm{ND}$ & $\mathrm{ND}$ & 2.67 & & & & & & \\
\hline anteiso- $\mathrm{C}_{17: 1}$ & 1.74 & 2.05 & 1.73 & & & & & & & 3 \\
\hline \multicolumn{11}{|c|}{ Summed features ${ }^{\star}$} \\
\hline 2 & ND & ND & ND & & & 1.55 & & & & \\
\hline 3 & ND & ND & $\mathrm{ND}$ & & & 2.18 & & & 6.70 & \\
\hline 4 & ND & ND & ND & 1.53 & & & & & 1.76 & \\
\hline 5 & ND & ND & $\mathrm{ND}$ & 2.30 & & & & & & \\
\hline
\end{tabular}

*Summed features represent groups of two or three fatty acids that could not be separated by GLC with the MIDI system. Summed feature 2 comprises iso- $\mathrm{C}_{16: 1}$ and/or $\mathrm{C}_{14: 0} 3-\mathrm{OH}$; summed feature 3 comprises $\mathrm{C}_{16: 1} \omega 7 \mathrm{c}$ and/or iso- $\mathrm{C}_{15: 0}$ 2-OH; summed feature 4 comprises iso- $\mathrm{C}_{17: 1}$ and/ or anteiso- $\mathrm{C}_{17: 1}$; and summed feature 5 comprises $\mathrm{C}_{18: 2} \omega 6 \mathrm{c}$ and/or anteiso- $\mathrm{C}_{18: 0}$. 
melibiose, stachyose, sucrose, trehalose, $p$-hydroxyphenylacetic acid, $\alpha$-ketoglutaric acid, $\alpha$-ketovaleric acid, propionic acid, succinamic acid, succinic acid, $N$-acetyl-L-glutamic acid, putrescine, 2,3-butanediol, 2'-deoxyadenosine, glucose 6phosphate and DL- $\alpha$-glycerol phosphate was detected (see Supplementary Table S1 in IJSEM Online). $\alpha$-Cyclodextrin, $\beta$-cyclodextrin, dextrin, glycogen, inulin, mannan, L-arabinose, D-arabitol, arbutin, cellobiose, D-fructose, L-fucose, D-galactose, D-galacturonic acid, gentiobiose, $\alpha$-D-lactose, lactulose, maltose, maltotriose, D-mannitol, D-mannose, melezitose, methyl $\alpha$-D-galactoside, methyl $\beta$-D-galactoside, methyl $\alpha$-D-glucoside, methyl $\beta$-D-glucoside, methyl $\alpha$-Dmannoside, palatinose, D-psicose, raffinose, L-rhamnose, D-ribose, salicin, sedoheptulosan, D-sorbitol, D-tagatose, turanose, xylitol, D-xylose, $\alpha$-hydroxybutyric acid, $\beta$-hydroxybutyric acid, lactamide, D-lactic acid methyl ester, L-lactic acid, D- and L-malic acid, methyl pyruvate, monomethyl succinate, alaninamide, D- and L-alanine, L-alanyl glycine, L-asparagine, L-glutamic acid, glycyl L-glutamic acid, Lpyroglutamic acid, L-serine, adenosine, inosine, thymidine, uridine, adenosine 5'-monophosphate, thymidine $5^{\prime}$ monophosphate, uridine $5^{\prime}$-monophosphate, fructose 6phosphate and glucose 1-phosphate were not utilized.

The cell wall of the type strain contained meso-diaminopimelic acid in the peptidoglycan, suggesting the occurrence of the peptidoglycan type A1 $\gamma$. The major isoprenoid quinone detected in strain $\mathrm{K} 1-5^{\mathrm{T}}$ was MK-7, and a minor amount of MK-6 was also detected. The cellular fatty acid compositions of strains $\mathrm{K} 1-5^{\mathrm{T}}, \mathrm{K} 1-10$ and B1-1 were dominated by anteiso$\mathrm{C}_{15: 0}$. Among the other major fatty acids, iso- $\mathrm{C}_{15: 0}$ and anteiso- $\mathrm{C}_{17: 0}$ were detected. The fatty acid profiles of the three strains were similar (Table 2). However, there are characteristic differences between $\mathrm{K} 1-5^{\mathrm{T}}, \mathrm{K} 1-10$ and $\mathrm{B} 1-1$ compared with their closest relatives (Bacillus cellulosilyticus, Bacillus clarkii and Bacillus vedderi). Strain K1 $-5^{\mathrm{T}}$ contained diphosphatidylglycerol, phosphatidylglycerol, phosphatidylethanolamine and an unknown polar lipid.

The DNA G + C content of strain $\mathrm{K} 1-5^{\mathrm{T}}$ was $42.9 \mathrm{~mol} \%$. The three strains exhibited high levels of DNA-DNA reassociation with one another $\left[\mathrm{K} 1-5^{\mathrm{T}}\right.$ with $\mathrm{K} 1-10,86.8 \%$ (repetition $89.6 \%$ ); K1-5 ${ }^{\mathrm{T}}$ with B1-1, $88.0 \%$ (repetition $91.8 \%$ ); K1-10 with B1-1, $95.3 \%$ (repetition 97.9\%)], demonstrating that the strains belong to the same species. The phylogenetic tree constructed from evolutionary distances of Kimura's two-correction parameter by the neighbour-joining method showed that strains K1-5 $5^{\mathrm{T}}$, K1-10 and B1-1 formed a cluster with B. clarkii DSM $8720^{\mathrm{T}}$, B. cellulosilyticus $\mathrm{N}-4^{\mathrm{T}}$, B. vedderi $\mathrm{JaH}^{\mathrm{T}}$, Bacillus agaradhaerens DSM $8721^{\mathrm{T}}$ and Bacillus saliphilus $6 \mathrm{AG}^{\mathrm{T}}$, with sequence similarities of 94.7-95.8, 94.5-95.7, 94.3-95.4, 93.9-95.2 and 92.2-93.3\%, respectively (Fig. 2). The nearly complete $16 \mathrm{~S}$ rRNA gene sequence of strain $\mathrm{K} 1-5^{\mathrm{T}}(1450 \mathrm{bp})$ had similarities of 98.7 and $97.6 \%$ to strains K1-10 and B1-1 (1462 and 1459 bp), respectively. Sequence similarity between strains K1-10 and B1-1 was 98.9\%. Phylogenetic trees created by the maximumlikelihood and least-squares algorithms resulted in similar topologies of the strains (data not shown) to the tree obtained by neighbour-joining method.

The described results of phylogenetic distinctiveness and phenotypic disparities indicate that strains $\mathrm{K} 1-5^{\mathrm{T}}, \mathrm{K} 1-10$ and B1-1 represent a novel species within the genus Bacillus, for which the name Bacillus aurantiacus sp. nov. is proposed.

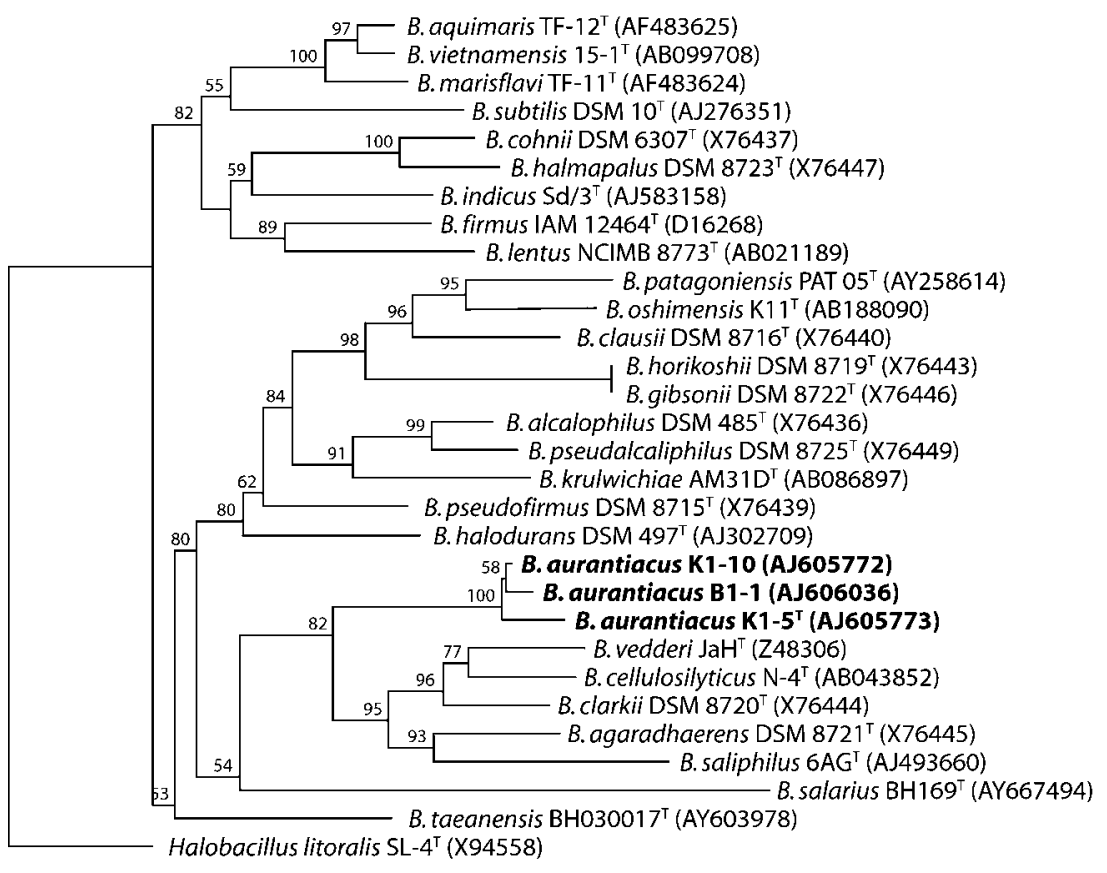

0.10
Fig. 2. $16 \mathrm{~S}$ rRNA gene sequence-based phylogenetic relationships of Bacillus aurantiacus sp. nov. strains $\mathrm{K} 1-5^{\top}$, B1-1 and $\mathrm{K} 1-10$ and closely related members of the genus Bacillus. The tree was constructed using the neighbourjoining algorithm. GenBank accession numbers are given in parentheses. Only bootstrap values above $50 \%$ are shown (1000 replications). Bar, 10 substitutions per 100 nucleotides. 


\section{Description of Bacillus aurantiacus sp. nov.}

Bacillus aurantiacus (au.ran.ti.a'cus. N.L. masc. adj. aurantiacus goldish-orange coloured).

Cells are Gram-positive, straight rods. Central to subterminal, ellipsoidal endospores are formed in unswollen sporangia. Cells are non-motile. Colonies are goldish-orange, circular, entire, smooth and convex. Obligately aerobic. Catalasepositive, oxidase-negative. Acid is not produced from Dglucose and nitrate is not reduced to nitrite. Voges-Proskauer and methyl-red reactions are negative. Urea, aesculin, casein and starch are not hydrolysed. Tyrosine decomposition and phenylalanine deamination are negative. Simmons' citrate is not used. Production of $\mathrm{H}_{2} \mathrm{~S}$ and indole is negative. Phosphatase is not produced. Tween 80 is hydrolysed. No growth is detected at $\mathrm{pH} 7.0-7.5$. Growth occurs between $\mathrm{pH} 8.0$ and 12.0. Growth occurs optimally at $\mathrm{pH} 9.5-10.0$ and with 3-7\% (w/v) NaCl. Temperature range for growth is between 10 and $45{ }^{\circ} \mathrm{C}$, with optimum growth at $28{ }^{\circ} \mathrm{C}$. Major fatty acids are anteiso- $\mathrm{C}_{15: 0}$, iso- $\mathrm{C}_{15: 0}$ and anteiso- $\mathrm{C}_{17: 0}$. The cell-wall peptidoglycan contains meso-diaminopimelic acid. The DNA G $+\mathrm{C}$ content of the type strain is $42.9 \mathrm{~mol} \%$.

The type strain, $\mathrm{K} 1-5^{\mathrm{T}}\left(=\mathrm{DSM} 18675^{\mathrm{T}}=\mathrm{CCM} 7447^{\mathrm{T}}\right.$ $=$ NCAIM B $002265^{\mathrm{T}}$ ), was isolated from sediment of Kelemen-szék, an extremely shallow soda lake situated in Hungary.

\section{Acknowledgements}

This research was supported by the Hungarian Scientific Research Fund (OTKA), grant T038021. The authors are grateful to Mrs Bettina Sträubler (DSMZ) for excellent technical assistance in performing the DNA-DNA hybridization.

\section{References}

Agnew, M. D., Koval, S. F. \& Jarrell, K. F. (1995). Isolation and characterization of novel alkaliphiles from bauxite-processing waste and description of Bacillus vedderi sp. nov., a new obligate alkaliphile. Syst Appl Microbiol 18, 221-230.

Barrow, G. I. \& Feltham, R. K. A. (2003). Cowan and Steel's Manual for the Identification of Medical Bacteria. Cambridge: Cambridge University Press.

Borsodi, A. K., Micsinai, A., Kovács, G., Tóth, E., Schumann, P., Kovács, A. L., Böddi, B. \& Márialigeti, K. (2003). Pannonibacter phragmitetus gen. nov., sp. nov., a novel alkalitolerant bacterium isolated from decomposing reed rhizomes in a Hungarian soda lake. Int J Syst Evol Microbiol 53, 555-561.

Borsodi, A. K., Micsinai, A., Rusznyák, A., Vladár, P., Kovács, G., Tóth, E. M. \& Márialigeti, K. (2005). Diversity of alkaliphilic and alkalitolerant bacteria cultivated from decomposing reed rhizomes in a Hungarian soda lake. Microb Ecol 50, 9-18.

Borsodi, A. K., Makk, J., Rusznyák, A., Vajna, B., Taba, Gy. \& Márialigeti, K. (2007). Phenotypic characterization and molecular taxonomic studies on Bacillus and related isolates from Phragmites australis periphyton. Aquat Bot 86, 243-252.

Cashion, P., Holder-Franklin, M. A., McCully, J. \& Franklin, M. (1977). A rapid method for the base ratio determination of bacterial DNA. Anal Biochem 81, 461-466.
Claus, D. (1992). A standardized Gram staining procedure. World J Microbiol Biotechnol 8, 451-452.

Collins, M. D., Pirouz, T., Goodfellow, M. \& Minnikin, D. E. (1977). Distribution of menaquinones in actinomycetes and corynebacteria. $J$ Gen Microbiol 100, 221-230.

De Ley, J., Cattoir, H. \& Reynaerts, A. (1970). The quantitative measurement of DNA hybridization from renaturation rates. Eur J Biochem 12, 133-142.

De Soete, G. (1983). A least squares algorithm for fitting additive trees to proximity data. Psychometrika 48, 621-626.

Felsenstein, J. (1981). Evolutionary trees from DNA sequences: a maximum likelihood approach. J Mol Evol 17, 368-376.

Felsenstein, J. (1985). Confidence limits on phylogenies: an approach using the bootstrap. Evolution 39, 783-791.

Groth, I., Schumann, P., Weiss, N., Martin, K. \& Rainey, F. A. (1996). Agrococcus jenensis gen. nov., sp. nov., a new genus of actinomycetes with diaminobutyric acid in the cell wall. Int J Syst Bacteriol 46, 234-239.

Groth, I., Schumann, P., Rainey, F. A., Martin, K., Schietze, B. \& Augsten, K. (1997). Demetria terragena gen. nov. sp. nov., a new genus of actinomycetes isolated from compost soil. Int J Syst Bacteriol 47, 1129-1133.

Hasegawa, T., Takizawa, M. \& Tanida, S. (1983). A rapid analysis for chemical grouping of aerobic actinomycetes. J Gen Appl Microbiol 29, 319-322.

Horikoshi, K. (1996). Alkaliphiles - from an industrial point of view. FEMS Microbiol Rev 18, 259-270.

Huß, V. A. R., Festl, H. \& Schleifer, K. H. (1983). Studies on the spectrophotometric determination of DNA hybridization from renaturation rates. Syst Appl Microbiol 4, 184-192.

Jones, B. E., Grant, W. D., Duckworth, A. W. \& Owenson, G. G. (1998). Microbial diversity of soda lakes. Extremophiles 2, 191-200.

Jukes, T. H. \& Cantor, C. R. (1969). Evolution of protein molecules. In Mammalian Protein Metabolism, vol. 3, pp. 21-132. Edited by H. N. Munro. New York: Academic Press.

Kimura, M. (1980). A simple method for estimating evolutionary rates of base substitutions through comparative studies of nucleotide sequences. J Mol Evol 16, 111-120.

Lim, J.-M., Jeon, C. O., Lee, S.-M., Lee, J. C., Xu, L.-H., Jiang, C.-L. \& Kim, C.-J. (2006a). Bacillus salarius sp. nov., a halophilic, sporeforming bacterium isolated from a salt lake in China. Int J Syst Evol Microbiol 56, 373-377.

Lim, J.-M., Jeon, C. O. \& Kim, C.-J. (2006b). Bacillus taeanensis sp. nov., a halophilic Gram-positive bacterium from a solar saltern in Korea. Int J Syst Evol Microbiol 56, 2903-2908.

Maidak, B. L., Olsen, G. J., Larsen, N., Overbeek, R., McCaughey, M. J. \& Woese, C. R. (1996). The Ribosomal Database Project (RDP). Nucleic Acids Res 24, 82-85.

Martins, R. F., Davids, W., Al-Soud, W. A., Levander, F., Radström, P. \& Hatti-Kaul, R. (2001). Starch-hydrolyzing bacteria from Ethiopian soda lakes. Extremophiles 5, 135-144.

Mesbah, M., Premachandran, U. \& Whitman, W. B. (1989). Precise measurement of the $\mathrm{G}+\mathrm{C}$ content of deoxyribonucleic acid by highperformance liquid chromatography. Int J Syst Bacteriol 39, 159-167.

Minnikin, D. E., Collins, M. D. \& Goodfellow, M. (1979). Fatty acid and polar lipid composition in the classification of Cellulomonas, Oerskovia and related taxa. J Appl Bacteriol 47, 87-95.

Murray, R. G. E., Doetsch, R. N. \& Robinow, C. F. (1994). Determinative and cytological light microscopy. In Methods for General and Molecular Bacteriology, pp. 21-41. Edited by P. Gerhardt, R. G. E. Murray, W. A. Wood \& N. R. Krieg. Washington, DC: American Society for Microbiology. 
Nielsen, P., Fritze, D. \& Priest, F. G. (1995). Phenetic diversity of alkaliphilic Bacillus strains: proposal for nine new species. Microbiology 141, 1745-1761.

Nogi, Y., Takami, H. \& Horikoshi, K. (2005). Characterization of alkaliphilic Bacillus strains used in industry: proposal of five novel species. Int J Syst Evol Microbiol 55, 2309-2315.

Rees, H. C., Grant, W. D., Jones, B. E. \& Heaphy, S. (2004). Diversity of Kenyan soda lake alkaliphiles assessed by molecular methods. Extremophiles 8, 63-71.

Romano, I., Lama, L., Nicolaus, B., Gambacorta, A. \& Giordano, A. (2005). Bacillus saliphilus sp. nov., isolated from a mineral pool in Campania, Italy. Int J Syst Evol Microbiol 55, 159-163.

Saitou, N. \& Nei, M. (1987). The neighbor-joining method: a new method for reconstructing phylogenetic trees. Mol Biol Evol 4, 406-425.

Smibert, R. M. \& Krieg, N. R. (1994). Phenotypic characterization. In Methods for General and Molecular Bacteriology, pp. 603-711. Edited by
P. Gerhardt, R. G. E. Murray, W. A. Wood \& N. R. Krieg. Washington, DC: American Society for Microbiology.

Stead, D. E., Sellwood, J. E., Wilson, J. \& Viney, I. (1992). Evaluation of a commercial microbial identification system based on fatty acid profiles for rapid, accurate identification of plant pathogenic bacteria. J Appl Bacteriol 72, 315-321.

Strunk, O. \& Ludwig, W. (1995). ARB - a software environment for sequence data. Department of Microbiology, Technical University of Munich, Germany. http://www.arb-home.de/

Tamaoka, J. \& Komagata, K. (1984). Determination of DNA base composition by reversed-phase high-performance liquid chromatography. FEMS Microbiol Lett 25, 125-128.

Yamada, K. \& Komagata, K. (1972). Taxonomic studies on coryneform bacteria. IV. Morphological, cultural, biochemical, and physiological characteristics. J Gen Appl Microbiol 18, 399-416. 